\title{
PEACE PROCESSES AND IDP SOLUTIONS
}

\author{
Patricia Weiss Fagen*
}

The forcible uprooting of people is an inevitable consequence of armed conflict. The processes by which peace agreements are negotiated and implemented will determine whether and under what conditions internally displaced persons (IDPs) will return home or whether other solutions will be necessary or possible. If countries newly emerging from conflict are able to find durable solutions for IDPs and other waraffected populations, it is a significant bellwether for the success of the overall peace process. IDP concerns arise most visibly in the humanitarian practices of government and insurgent parties prior to the conclusion of an overall peace agreement. Subsequently, the language in peace agreements about procedures for refugee returns also encompasses IDP questions. Over the long term, the integration of IDPs depends on the local, regional, and national implementation of agreed principles. International monitoring of local implementation is weak at best.

\section{Introduction}

The forcible uprooting of people is an all-too-frequent human consequence of armed conflict. Internally displaced persons (IDPs) include people who have fled their communities because they were caught in the crossfire between armed parties or whose displacement was a deliberate strategy pursued by combatants. The processes by which peace agreements are negotiated and implemented will determine whether IDPs are able to return home - and, if so, under what conditions - or whether other solutions will be necessary or possible. IDPs not only have deep vested interests in peace processes, but often strong opinions about both the issues and the negotiators. The parties sitting around the negotiating table inevitability include individuals who played a role in the uprooting of communities.

This article focuses on peace processes and peace agreements, and considers the extent and the manner in which they address issues related to IDPs. These issues arise, sequentially, at three phases in the peace process: in the humanitarian measures and the options made available to IDPs by both government and insurgent parties prior to the conclusion of an overall peace agreement between them; in the language agreed by the parties and incorporated into the peace

\footnotetext{
* Patricia Weiss Fagen has a doctorate and is Senior Associate at the Institute for the Study of International Migration, Georgetown University. This article is derived from an unpublished report prepared for the Brookings-Bern Project on Internal Displacement.
}

Refugee Survey Quarterly, Vol. 28, No. 1 (C) UNHCR [2009]. All rights reserved.

For Permissions, please email: journals.permissions@oxfordjournals.org

DOI:10.1093/rsq/hdp004 
accords; and in the local, regional, and national implementation of agreed principles.

If countries newly emerging from conflict are able to find durable solutions for IDPs and other war-affected populations, it is a significant bellwether for the success of the overall peace process. IDP issues, including status, locations, means of livelihood, and human rights are negotiated in a politicized context. While all parties may agree on the importance of finding humanitarian solutions, they will have diverging interests with regard to specific elements of those solutions. The outcomes of negotiations covering security, institutional reform, human rights, removal of discriminatory laws and practices, and creation of participatory democratic mechanisms are relevant for IDPs and the society as a whole. At the same time, there are issues related specifically to ending displacement, including ensuring IDP rights to choose where to settle, to recover losses, and to acquire or replace personal documents. These points may not be discussed in detail at the negotiating table. They are more likely to be referenced but not elaborated in the actual agreements. Understandably, peace negotiations focus primarily on issues that reflect the competing demands of the adversaries, foremost among them being security and governance.

Typically, peace agreements are organized in chapters or protocols, sometimes signed separately and at different times. Although the agreements are rooted in each country's particular experiences of conflict, they usually encompass some version of the following: general principles; modalities to implement the cessation of hostilities; the disarmament, demobilization, rehabilitation, and reintegration (DDRR) of former combatants; security sector issues (armed forces and police); human rights; humanitarian issues; transitional political structures and elections; and international support. References to the internally displaced, if they are present, are usually found in the sections on general principles, in the chapters on human rights and humanitarian issues, under implementation provisions, and in requests for international support. Governments are ultimately responsible for implementing the agreements. United Nations (UN) missions and international humanitarian organizations, however, often assume major responsibilities for implementation in the early years, especially in the humanitarian field.

IDP issues are being incorporated into contemporary peace agreements as a result of the influence of international organizations and advocacy by national civil society, including human rights and IDP organizations. The rather discouraging trajectory of IDPs and other war-affected populations following conflict, however, makes it clear that strong commitments written into peace agreements are insufficient in themselves to bring about durable solutions. It is therefore essential for the entities that bring IDP issues to the table prior to the resolution of conflict to remain vigilant after the conflict has ended in order to ensure that negotiated agreements are implemented. The policies and actions of local authorities and traditional leaders remain important throughout the peacebuilding process. 
The first section of this article considers the extent to which IDP and refugee issues overlap in peace processes, especially during return. The second section discusses the ways in which issues of displacement and the displaced themselves are included in peace negotiations, using examples from selected peace agreements around the world. The next section focuses on the cases of Guatemala, Bosnia and Herzegovina, Liberia and Burundi to examine the extent to which the commitments made in peace agreements are actually implemented. These cases are intended to illustrate achievements and shortfalls of IDP reintegration in the context of peacebuilding efforts. The next section briefly discusses the particular issues that arise in countries where displacement has been ongoing for many years as a result of protracted conflict and where peace processes have not succeeded. The final section elaborates the article's main conclusions.

\section{IDPs, refugees, and peace processes}

In practice the measures taken during peace processes on behalf of returning refugees and IDPs overlap. It is important, however, to understand both the commonalities and differences in the respective situations of these two groups. In general, the differences are sharpest prior to peace agreements when IDPs are usually at greater risk than refugees. The former are frequently in places where they have no access to international assistance even if such assistance might potentially be available. Under the best conditions, assistance to IDPs, as compared with refugees, is more sporadic and their livelihoods more fragile because they are living in countries subject to civil strife. Populations in conflict zones may be repeatedly displaced, and are highly vulnerable. IDPs living in areas under the control of insurgent groups may be treated as enemy combatants by government forces, and vice versa.

IDPs continue to be at a disadvantage vis-à-vis refugees during peace negotiations. When parties to a peace agreement are negotiating the terms on which they will end a conflict, it is customary to put the question of refugee return formally on the agenda, and to consult with the Office of the United Nations High Commissioner for Refugees (UNHCR) about timing, modalities and rights upon return. UNHCR in effect is the representative of the refugees who are themselves not present at the peace table. Because refugees are on somebody else's territory, host country governments are usually also part of the process. The objective is normally to ensure that refugee returns are voluntary and conducted in a peaceful and orderly manner. In contrast, IDPs rarely have a designated representative in peace negotiations, although sometimes one of the parties to a conflict claims to represent segments of war-affected populations, including IDPs. Often international "friends" in a peace process will advocate on behalf of IDP rights. Civil society groups have also at times represented IDP interests to the parties at the negotiating table and have brought their expertise to bear. 
Once refugees have returned to their counties of origin, UNHCR negotiates the restoration of their rights, monitors their situation, and denounces human rights violations. In addition, UNHCR provides temporary assistance to refugee returnees, including, when possible, those who return spontaneously. IDPs, regardless of the situation that gave rise to their flight, do not necessarily benefit from the same forms of protection and assistance.

In recent years, however, international recognition that IDPs have similar protection and assistance needs to those of refugees has grown, especially as the result of the efforts of humanitarian advocates and the Representative of the Secretary-General on Internally Displaced Persons (after 2004 on the Human Rights of Internally Displaced Persons) and his staff. Governments across the globe have accepted responsibility for assisting and protecting the internally displaced, as stipulated in the 1998 Guiding Principles on Internal Displacement. UNHCR and other international agencies have considerably strengthened their commitments to assisting and protecting IDPs in several countries.

During and after conflict, UNHCR programmes generally include IDPs located in areas to which refugees are returning or in nearby areas. In cases of large-scale refugee returns, UNHCR has long emphasized the importance of community-based assistance which benefits war-affected populations overall. The mandates of several international agencies operating in conflict and postconflict countries, including the Office for the Coordination of Humanitarian Affairs (OCHA), the United Nations Development Programme (UNDP), the Office of the High Commissioner for Human Rights (OHCHR), the UN Children's Fund (UNICEF), the World Food Programme (WFP), and the International Organization for Migration (IOM), also include IDPs in the context of other war-affected and vulnerable groups. So do international nongovernment agencies. For their part, governments create national entities to liaise with the UN bodies.

Recent initiatives within the UN system to achieve better coordinated responses and to fill gaps in assistance and protection promise to give more equal treatment to returning refugees and IDPs. The "cluster approach" adopted by the Inter-Agency Standing Committee (IASC) in 2005 assigns lead agency responsibilities to specific organizations for major issues, including protection, health, water and sanitation, early recovery, and logistics, and should increase the effectiveness of the UN's response to IDPs. The lead agency coordinates all activities and projects in its domain of leadership. UNHCR is the lead agency for protection, emergency shelter, and camp coordination and camp management for conflict-displaced IDPs, and oversees IDP and refugee return in operations where the cluster approach has been adopted. In Liberia, one of the pilot countries for this approach, UNHCR assumed cluster leadership for these issues as of July 2005. ${ }^{1}$ In the Democratic Republic of the Congo, another pilot

1 Jesuit Refugee Service (JRS), Six Months after the Official Closing of the Camps: JRS Assessment of the IDP Return Process, 19 Dec. 2006, 9. 
country, UNHCR offered the same return packages to IDPs as refugees, regardless of the communities to which they returned. ${ }^{2}$ The cluster approach, obviously, does not eliminate problems brought about by lack of resources, lack of political will, or inadequate national capacities to follow through.

\section{Incorporation of IDP issues into past peace agreements}

Peace agreements establish the political, legal, and humanitarian obligations that governments should assume toward IDPs. There is almost always positive rhetoric, which may or may not be accompanied by actionable commitments.

An initial consideration is whether the language used in the peace agreements commits the parties to actions that cover both refugees and IDPs. For the most part, this is presently the case. The specific inclusion of gender in the proposals is also of direct relevance to IDP communities given the preponderance of women in war-affected communities and their particular issues of vulnerability.

A second consideration is the degree of specificity on such key questions as the modalities of return (and alternatives to return), the obligation to restore or compensate for lost property; basic rights of citizenship, personal documentation, and so on. It is important to note that "return" is a relative term. Because they so often lack opportunities in rural areas, returning refugees around the world tend to gravitate to cities and towns. Rural IDPs displaced over a long period of time in urban locations also tend to remain there. Their presence adds to the burdens already placed on infrastructure, social services, and poverty alleviation efforts. Agreements to provide compensation for lost livelihoods, which could lift displaced persons out of poverty, are problematic.

A third consideration - all too often the Achilles heel of peace processes is the effectiveness of provisions put in place for defining and implementing the above measures. Also at issue here are both physical obstacles that may prevent compliance as well as political will.

The fourth main consideration concerns the costs of compliance - that is, how the agreements anticipate funding, administering and managing IDP settlement in another part of the country, integration, compensation, restitution, economic revitalization, and so on - given the long list of numerous and costly items on the post-conflict recovery priority list.

\subsection{Inclusive language}

In 1989, the International Conference on Central American Refugees (CIREFCA) broke new ground by recognizing forced displacement as a region-wide problem to be addressed in the context of the Central American

2 Internal Displacement Monitoring Centre (IDMC), DR Congo: IDP Return Picks up Despite Glaring Lack of Reintegration Support, 31 Oct. 2006, 8. 
peace process, and by tying international humanitarian assistance to human rights, reconciliation, and dialogue. Governments from the region, international organizations, donors, and representatives from civil society attended the meeting. The agreement that emerged did not differentiate between refugees and IDPs for the purposes of access to assistance or participation in nationally and internationally funded project initiatives. Project proposals, often from grassroots sources, were vetted, through 1994, by a Joint UNHCR-UNDP Joint Support Unit. ${ }^{3}$ During the conflicts, women had achieved significant organization and voice among both refugee and to a lesser extent internally displaced populations, and consequently gender awareness was also promoted throughout. In large part because of the CIREFCA agreement and regional peace process, refugees from El Salvador and Guatemala repatriated collectively to their own country in movements negotiated by their own leaders, UNHCR, and the governments prior to formal peace agreements. Although they were not included in these negotiations, IDPs also returned. The separate peace agreements that followed in El Salvador (1992) and Guatemala (1994) were crafted with a comprehensive definition of victims of forced displacement, strongly influenced by CIREFCA, and the previous accords negotiated with refugee returnees.

\subsection{Specificity of commitments and modalities}

In ending the conflict in countries that have experienced major displacement, the parties invariably make commitments to respect full political rights, the right of return, freedom of movement, religious freedom, ethnic diversity, and so on. The wording in the agreements ranges from general commitments meant to apply to the population at large to detailed measures applicable to IDPs and/or refugees.

Peace agreements in Burundi, Bosnia and Herzegovina, Cambodia, Guatemala, Mozambique, and Sierra Leone have not only recognized the right to return and enjoy human rights, but also specifically mention IDP and refugee rights related to citizenship, property recovery, and special needs. The 1992 Mozambican Peace Agreement, for example, specifies that "the Government shall draw up a draft agreement with Renamo [the insurgent Mozambican National Resistance] to organize the necessary assistance to refugees and displaced persons, preferably in their original places of residence". ${ }^{4}$ It goes on to seek involvement of the UN and other international agencies and international

\footnotetext{
3 A. Betts, Comprehensive Plans of Action: Insights from CIREFCA and the Indochinese CPA, Working Paper No. 120, UNHCR New Issues in Refugee Research, Jan. 2006; P. W. Fagen, "Peace in Central America: transition for the uprooted", in US Committee for Refugees, World Refugee Survey, Washington DC, 1993, 30-39; P. Worby, Lessons Learned from UNHCR's Involvement in the Guatemala Refugee Repatriation and Reintegration Programme, 1997-1999, UNHCR, Regional Bureau for the Americas and Evaluation and Policy Analysis Unit, 10 Feb. 2000.

4 Mozambique, General Peace Agreement, Protocol III, IV, (b).
} 
funding for assistance programmes. It affirms that displacement will not result in any loss of citizenship rights; and that all displaced people will be registered and included on electoral rolls. In the agreement, the state also guarantees restitution of property and commits to facilitating legal action against those illegally possessing said property.

Thus, refugees and IDPs appear side-by-side in the same paragraphs of peace agreements, and international agencies increasingly assume similar responsibilities for both groups. However, refugees still retain the advantages derived from having received assistance, education and health care, and protection in refugee camps, and from having participated in negotiations regarding their own repatriations.

\subsection{Effective implementation}

That formal peace agreements today often incorporate measures for the protection and reintegration of IDPs and recognize that they have lost basic rights which must be restored to them is indeed positive. Less encouraging is the fact that positive language in the agreements is undermined time and again by lack of robust implementation. Points left vague in the body of the agreement may become subject later on to drawn-out negotiations; judicial arrangements created to oversee compliance and settle differences may not operate at local levels; other post-conflict priorities almost always take precedence; and momentum declines. Mechanisms of execution for the different segments of peace agreements, terms of reference and accountability of executing bodies vary greatly. Access, resources, and decision-making authority are problematic.

There is a dearth of analysis of national bodies created to oversee peace agreements in general, not just agreements related to IDPs. More research should be devoted to examining and analyzing the actual implementation of agreements.

UN Missions have attributed weak national compliance variously to poor conditions, poorly trained local personnel, lack of financial support, and unforeseen and/or insurmountable obstacles (for example, landmines). Local hostility, national indifference, continuing security threats from one or several of the former parties to the conflict, and lack of accountability for human rights violations also figure prominently. Even where political will exists, as it does, for example, in Liberia and Sierra Leone, it is difficult for newly installed governments to exercise their authority to ensure IDP rights are respected, given the many other serious challenges they face. In nearly all countries covered in background research for this article, IDPs and other war-affected populations continue to endure extremely difficult conditions following peace agreements.

Sudan and Bosnia exemplify how well-worded agreements can be undermined by lack of political will. Although Southern Sudan signed a Comprehensive Peace Agreement with the North in January 2005, conflict persists and distrust prevails. The autonomous Southern Sudanese government 
in Juba and local leaders in the south have received approximately 1.9 million IDP and refugee returnees since then. ${ }^{5}$ These include especially large numbers of women and young people. The south has promised to welcome however many more of the estimated 4 million displaced people who may arrive. However, it lacks resources and capacity to integrate them properly.

The Sudanese government maintains a dual policy. In keeping with the North-South peace agreement of January 2005, it does not impede the movement of the millions of refugees and IDPs who choose to return to Southern Sudan, and there is cooperation on humanitarian issues between north and south in the country. On the other hand, the Khartoum government thus far has resisted implementing measures in the Comprehensive Peace Agreement that have a bearing on the future of war-affected populations. Specifically, it has not acted on the decisions of the Abyei Boundary Commission report of 2005 , one of the key protocols to emerge from the peace talks. ${ }^{6}$ It continues to resist integrating the IDP population still remaining in the north, which mainly lives in and around Khartoum.

The most comprehensive and detailed of the endeavours to codify IDP and refugee solutions in a peace agreement is the December 1995 General Agreement for Peace in Bosnia and Herzegovina (Dayton Accord). Annex Seven of the Dayton Accord directs national authorities and international entities as to the tasks to be undertaken and assigns responsibility for fulfilling them. The agreement lists the measures to be enforced and affirms the responsibility of political authorities to punish those who violate them. The international negotiators considered ethnic hostilities and displacement as the underlying causes of the conflict and thus as essential to be addressed. However, the agreement ultimately failed to reproduce the multi-ethnic society which was lost in the conflict. While there were many reasons, which are elaborated in greater detail below, the fundamental problem was that the Dayton Accord was imposed upon - rather than agreed by - the parties to the conflict. Of all the measures in the agreement, moreover, those aimed at restoring ethnic diversity met with the most resistance.

An important test of durable peace is how and whether IDPs who return to their places of origin after peace agreements become productive citizens; and how and whether those who resettle in places other than their original communities are integrated. Systematic studies of these phenomena are rare; therefore it is difficult to verify how the commitments in peace agreements are implemented. No single entity currently has responsibility for monitoring this phenomenon. UNHCR monitors its own programmes, and adds whatever context appears relevant; human rights organizations track violations, but rarely disaggregate

UN Mission in Sudan, Return, Reintegration and Recovery, Information Management Office, "Sudan IDP \& Refugee Returns, Reintegration Operations Statistical Overview”, Jan. 2009, available at: http://www.internaldisplacement.org/8025708F004CE90B/(httpDocuments)/FEED5CE5022A706CC125753E003F3046/ \$file/Returns_RRR-Jan09.pdf (last visited 3 Feb. 2009).

6 Abeye is a contested area between tribes of north and south. The Boundary Commission was made up of five international boundary specialists and one representative from each side. 
victims according to whether or not they are returnees; OCHA and other humanitarian groups furnish information on whether conditions are conducive to receiving IDPs or other returnees, but do not track them. Compliance regarding commitments to IDPs in peace agreements related to property, compensation, documentation, discrimination, and so on are selectively documented.

UN special missions, working with governments to implement peace accords, report regularly to the Secretary-General. These reports offer the most comprehensive source on compliance. Theoretically, the UN Missions must report on any IDP-related issues noted in the peace agreements. In practice, reporting on IDPs is weak and unsystematic and reporting on returning refugees is not much better. Understandably, the UN Missions are most concerned with keeping difficult peace arrangements from unravelling. Their attention is focused on the major political actors, on the one side and, on the other, the "spoilers" whose resort to violence and human rights abuses undermines stability. The reports of international observers offer little information about the progress made either on meeting the needs of vulnerable populations like IDPs, or on the political will and technical capacities of government entities assigned to these tasks.

IDPs themselves are both a source of information about their condition and important - or potentially important - advocates for national and international attention. In nearly all countries where they are numerous and live in concentrated settlements, they are organized and regularly petition for their rights. However, they are all too often divided on goals and strategies. Some IDP groups are narrowly focused on immediate demands for improvements; others are linked to political leaders who have broader agendas. Still other groups argue against integration strategies, fearing that integration could dilute their right to return.

\subsection{The costs of compliance}

Peace agreements are today almost always made in the presence of, or in close consultation with, international actors. In Cambodia and Bosnia and Herzegovina, for instance, international actors had a stronger say in the measures adopted than did the actual parties to the conflict. All parties to the negotiations normally recognize that war-torn countries are not likely to be able to meet the pressing needs of large numbers of people in need of reintegration in the short term. Therefore, the documents signed by the parties often contain clauses proposing that international actors furnish technical and financial support to facilitate compliance with the material requirements of IDP return and reintegration, local settlement, and/or settlement elsewhere.

For example, the July 1999 Sierra Leone Agreement (Part five, article XXII) states:

The Parties ... agree to seek funding from and the involvement of the UN and other agencies, including friendly countries, in order to design and 
implement a plan for voluntary repatriation and reintegration of Sierra Leone refugees and internally displaced persons ...

The July 2002 Sudanese Peace Agreement (section 15 Reconstruction and Development Funds. 15.1) states:

There shall be established a Southern Sudan Reconstruction and Development Fund (SSRDF) to solicit, raise and collect funds from domestic and international donors and disburse such funds for the reconstruction and rehabilitation of the South, for the resettlement and reintegration of internally and externally displaced persons ...

In other words, the well-being of IDPs, refugees, and all other war-affected populations and vulnerable groups is very much dependent on international generosity. The amount of assistance, its form, and its duration, in turn, have a strong impact on future development. In Mozambique, for instance, displacement was so massive that returnees came back to regions that had been practically depopulated. This meant local structures and capacities had to be rebuilt and communities re-established. ${ }^{7}$ The task fell essentially to international humanitarian actors and as late as 2003 donor aid was still the equivalent of half the state's public expenditure. External aid has helped to rebuild the country and secure an enduring peace but the government still lacks sufficient wherewithal and capacity to manage or generate resources over the long term. Donors have not significantly changed their practice of giving project aid rather than direct budget support, and specifying how the funds are spent. ${ }^{8}$

In most countries that suffer massive forced displacement, the end of conflict leaves enormously swollen cities. People who have left conflict-affected rural areas are more likely to remain in their place of displacement than to return; often they cannot return. Yet, international assistance is primarily targeted at return to places of origin and allocates little to urban integration. In so far as there are assistance programmes for IDPs in urban settings, as in Colombia, these are limited to short-term emergency relief.

\section{Peace agreements in selected countries}

\subsection{Guatemala, 1979-99}

The IDP and refugee populations in and from Guatemala were comprised largely of indigenous groups, who had been driven from their land and communities with genocidal ferocity during the late 1970s and 1980s while the country was under military rule. They have always suffered extreme poverty and discrimination. As a result of this forced displacement, about 42,000

\footnotetext{
7 "Report of the Representative of the Secretary General Mr Francis M. Deng to the UN Commission on Human Rights", E/CN.4/1997/43/Add.1, 24 Feb. 1997.

8 A. Hodges and R. Tibana, "Reducing Mozambique's reliance on donor aid”, UNICEF, 8 Nov. 2006 and R. Batley, "The costs of government 'owned' aid in Mozambique", 13 Sep. 2006, both available at www.Id21.org (last visited 5 Jan. 2009).
} 
Guatemalans crossed the border and remained in refugee camps in Mexico (another 50,000 or so sought asylum outside of the camps), while about 1 million (variously estimated at different times) were displaced within Guatemala.

Guatemalan refugees in Mexico organized and during the early 1990s negotiated with the Guatemalan Government for collective returns. This was an extraordinary endeavour on many counts: the refugees were poor and long exploited, spoke mutually incomprehensible languages and were not always fluent in Spanish - certainly a hurdle for negotiations. Contrary to tradition and culture, female refugees were active in the movement. The context was highly politicized, which added to the Guatemalan Government's reluctance to agree to their demands. However, in 1992 after protracted negotiations and with the help of UNHCR, the 8 October accords were signed between the refugees organized in their Permanent Commissions and the Guatemalan Government. In addition to guaranteeing compliance with already existing constitutional rights, the accords ensured specific benefits, exemptions, and mechanisms for the returnees to acquire land. The first collective return took place in January 1993, a year before the first of the relevant peace accords was signed.

The negotiating parties to the peace agreements which followed concluded a total of eleven separate peace accords over the course of 3 years (January 1994 to December 1996). The negotiations, which continued for over 5 years, included consultations with refugee and, to a lesser extent, IDP organizations. The Guatemalan peace accords were unique in the participatory manner with which they were drafted and the thoroughness with which major issues were separately and comprehensively considered. The negotiating pattern reproduced many of the elements used in relation to the earlier negotiations between the refugees and the government. ${ }^{\text {? }}$

A separate agreement on displacement, signed in Oslo on 17 June 1994 and entitled "Agreement on the Resettlement of Population Groups Uprooted by the Armed Conflict", affirms that resettling the uprooted population is "an important component of a firm and lasting peace". It pledged to find lasting solutions in "a framework of social justice, democratization and sustainable and equitable national development" ${ }^{10}$ That agreement accelerated the ongoing refugee return from Mexico and the resettlement of locally uprooted people elsewhere in the country. Other agreements further buttressed the rights of uprooted people, including "The General Agreement on Human Rights" (29 March 1994), "The Agreement on the Identity and Rights of Indigenous People" (31 March 1995), and "The Agreement on Socio-Economic Aspects of the Agrarian Situation" (9 May 1996).

In terms of inclusiveness of language and specificity of measures, the Guatemalan pace accords are a model. It refers to the displaced population not as a homogeneous whole but with reference to its component parts,

P. Worby, Lessons Learned, op. cit. 3, 5.

10 Preamble, Agreement on Resettlement of the Population Groups Uprooted by the Armed Conflict, Jun. 1994. 
including indigenous peoples, women, children, poor, and landless peasants. It firmly links reintegration with poverty alleviation and political participation, and requires the cooperation of local officials. It contains sections on needed educational programmes, health benefits, social services, and acknowledges the urgency of providing personal documentation. Much of its content focuses on land, the basic component of what the parties refer to as productive integration, that is, land for resettlement, land use, legal titles to land, credits and land improvement, and rural productivity.

The commitments made to IDPs in the 1994 peace agreement were not as concrete as those previously negotiated in 1992 between the refugees and the government, and implementation mechanisms were vague. The June 1994 Resettlement Accord created a Technical Commission (CTEAR) [article V(2)], a representative body that included returnees along with government and international observers. It became operational after the peace agreements overall were concluded in December $1996 .{ }^{11}$ CTEAR's initial charge was to conduct studies on land availability and on the needs of the displaced population and to propose projects to meet those needs, which were submitted to potential international donors. Neither CTEAR nor any other state body actually executed projects or programmes or had jurisdiction over assistance to IDPs. In 1997, the Government signed an agreement with IDP representatives, promising to address some of their needs, ${ }^{12}$ but announced that IDP assistance would come under general programmes covering extreme poverty. Thus, while IDPs benefited from the rights confirmed in the peace accords, their specific needs were not addressed institutionally in the same way as those of refugees. ${ }^{13}$

Likewise, international oversight was not well defined. UNHCR was already monitoring returnees, but its mandate was mainly limited to refugees. IDPs were included only when the two groups overlapped in returnee communities. The other UN entities lacked specific mandates for IDPs, although they sometimes addressed IDP problems through inter-agency cooperation. The IDPs themselves, with the exception of one small militant sector in the Communities of People in Resistance, were weakly organized. Hence, returning IDPs on the whole obtained fewer advantages than returning refugees.

More than 2 years after the agreement was signed, the UN Mission on Verification of the Guatemalan Peace Accords (MINUGUA) reported to the UN Secretary-General with a list of political, legal, and economic measures in the peace accords that were related to displacement and had not yet been implemented. ${ }^{14}$ The subsequent UN Mission Report of September 1998 found that few of the anticipated land transfers had taken place, and that there were delays in setting up the credit mechanisms. The Report commented: "Although the productive integration of the uprooted population cannot be dissociated

\footnotetext{
11 P. Worby, Lessons Learned, op. cit. 3, 46.

12 US Committee for Refugees, World Refugee Survey, Washington DC, 1999, 266.

13 P. Worby, Lessons Learned, op. cit. 3, 47.

14 Informe del Secretaria General, 1 Jan. to 31 Jul. 1998, 8.
} 
from the implementation of a comprehensive rural development strategy, the Mission reiterates that there is an urgent need for concrete, specific measures to alleviate the situation of uprooted population groups." It goes on to cite examples of important projects for which international funding was available, that were not being implemented. ${ }^{15}$

UNHCR reviewed its experience with Guatemalan refugees in 1999, following a dramatic reduction in its budget and the planned phasing-out of its Guatemala programme. Its analysis was focused on what remained to be done in the refugee communities that UNHCR had been serving but the concerns applied as much or more to IDPs:

Despite efforts by UNHCR and other agencies to promote sustainable reintegration of the returnee population in Guatemala, a number of problems still require the attention of the government, donors and NGOs. They include: Further support and capacity-building for community organization (particularly for women); legalization of land tenure in returnee communities to ensure women's access to land; longer-term support for agricultural projects; further improvements to social services in areas of return; access to employment opportunities in areas where agricultural production is limited; and attention to children's and adolescents' needs. ${ }^{16}$

Weak compliance with respect to returnees was symptomatic of weak compliance with the peace agreement as a whole. After the end of the civil conflict in Guatemala, economic and political power structures and the unequal land tenure system have remained essentially the same. The terms of the peace agreement remain poorly implemented despite a long-term UN presence, large donor contributions, and - more recently - serious government efforts to carry them through. Land owners have opposed the land concessions made to returnees, the military has continued to wield substantial power in parts of the country albeit not at the level of past repression - and wealthy Guatemalans have managed to avoid paying the taxes that are needed for social programmes to benefit all Guatemalans. The refugees and IDPs who returned and settled locally or elsewhere have struggled against violence, repression, and continuing poverty. The land tenure situation that received unprecedented attention in the peace accords benefited some groups among the returnees but, in the absence of a judicial system able to enforce the measures fairly, the land tenure situation also resulted in illegal takeovers and violent confrontations among the peasant population. ${ }^{17}$

15 UN Verification Mission in Guatemala, Report of the Secretary-General, Third report on the verification of compliance with the agreements signed by the government of Guatemala and the Unidad Revolucionaria Nacional Guatemalteca (URNG), A/53/421, 28 Sep. 1998, para. 12.

16 UNHCR, Guatemala/Mexico, Repatriation, Reintegration, and Local Settlement at a Glance, Special Report, 1999.

17 D. Azpuru, "Peace and democratization in Guatemala", in C. J. Arnson (ed.), Comparative Peace Processes in Latin America, Washington DC, Woodrow Wilson Press, 1999, 120. 


\subsection{Bosnia and Herzegovina ${ }^{18}$}

The brutal war fought from 1992 to 1995 in Bosnia and Herzegovina and in Croatia, all formerly part of the Federal Republic of Yugoslavia, dramatically altered the pre-war demography. Serbian aggression was intended to achieve ethnic uniformity by forcibly displacing the non-Serb, primarily Muslim, population. In Bosnia and Herzegovina, the war produced approximately 1.2 million refugees, about the same number or more of IDPs and resulted in at least 200,000 deaths $^{19}$ out of an initial population of about 4.4 million. The population thus fell by about one half between 1991 (before the conflict) and 1995 and, of those remaining, more than 50 per cent were displaced from their original areas. By the time the war was brought to a close in December 1995, Bosnian cities, towns, and rural communities were sharply segregated along ethnic lines. Additionally, following the war, the once moderately prosperous Bosnia was in ruins. Close to two-thirds of homes had been wholly or partially destroyed; and factories, schools, medical facilities, and communications networks had been destroyed. The gross domestic product (GDP) in Bosnia declined by about 75 per cent between 1991 and $1995 .^{20}$ Billions of dollars were needed to rebuild and restore the economy.

The General Framework for Peace in Bosnia and Herzegovina (GFAP), commonly known as the Dayton Peace Agreement, recognized the de facto creation of two separate ethnically defined entities: the Federation of Bosnia and Herzegovina and the Republika Srpska. Bosniacs (Muslims) and Croats uneasily shared the former, while the population in the latter was almost exclusively Serb. This division confirmed the reality that decentralized ethnic authority was a sine qua non for the parties' acceptance of the accords. At the same time, annex 7 of the Agreement was unprecedented in its detail on the mechanisms for return and the restoration of minority rights. International negotiators intended to ensure that forcibly displaced Bosnians would be allowed to return without "harassment, intimidation, persecution, or discrimination, particularly on account of their ethnic origin, religious belief or political opinion". The Dayton Accords placed great emphasis on protection measures, insisting that national and local authorities treat both refugees and IDPs equally in accordance with "the human rights and fundamental freedoms of all persons within their jurisdiction".

18 P. W. Fagen, "Post-conflict reintegration and reconstruction: doing it right takes a while", in N. Steiner, M. Gibney and G. Loescher (eds), Refugee Protection: The UNHCR, Refugees and Human Rights, NY, Routledge, 2003, chapter 11; P. W. Fagen "The long term challenges of reconstruction and reintegration: Case studies of Haiti and Bosnia-Herzegovina”, in E. Newman and J. van Selm (eds), Refugees and Forced Displacement, International Security, Human Vulnerability, and the State, United Nations University, Tokyo, Japan, 2003, chapter 11.

19 UNHCR, The State of the World's Refugees: Fifty Years of Humanitarian Action, Oxford, UK, Oxford University Press, 2000, 219.

20 N. Dahrendorf and H. Balian, The Limits and Scope for the Use of Development Assistance and Disincentives for Influencing Conflict Situations: Case Study: Bosnia, Paris, OECD/DAC Task Force on Conflict, Peace and Development Cooperation, Jun. 1999, 13-14. 
The goals were to be achieved with international oversight and humanitarian coordination under UNHCR leadership. The Dayton Accords established a structure open to international intervention in every sphere. The Office of the High Representative (OHR), with UNHCR in the lead, assumed responsibility for the return of refugees and IDPs. In addition, virtually all donors targeted their assistance in some fashion at promoting return and enhancing political will to receive returnees.

During 1997 and 1998 the donors' strategy was to use resources as incentives to induce minority returns by means of initiatives designed for maximum visibility. The initiatives focused primarily on rewarding Bosnian municipalities and communities that were willing to collaborate, as well as on removing physical and economic obstacles to return for those contemplating such action. Returning families from Europe were offered cash advances. Attracting minority returns with economic incentives, however, was insufficient so long as security issues and legal rights remained unresolved. A combination of persistent political intransigence, international misjudgments, and premature refugee returns first swelled the population of IDPs in the country and finally reinforced ethnic separation. The early international attempts to manage return movements in Bosnia and Herzegovina were based on false assumptions and the large quantity of money spent in the process was not always well directed.

Annex 7 to the Dayton Agreement created institutions designed to ensure durable return, one of the most important elements of which was a quasiinternational Commission for Real Property Claims (Chapter 2) for resolving property restitution claims. Thousands of claims were made, but the entity could do little until the UN pushed through a strong Property Law Implementation Plan (PLIP) in 1999. The PLIP reversed the incentives strategy and, in its place, introduced strict and systematically applied enforcement measures. Between 1999 and 2003, the PLIP mechanism resolved the majority of outstanding claims and even brought about a sharp increase in minority returns. ${ }^{21}$ Nevertheless, processing claims remained cumbersome and difficult. Flats were occupied by persons other than the original owners and if the owners moved back, the occupants were displaced. Owners of reclaimed property frequently chose not to live there - for economic reasons more often than because of ethnic tensions. In the end, although property claims were settled, the displaced did not return in large numbers to areas where they had been in the ethnic minority.

Notwithstanding the failed attempt to reverse ethnic cleansing, Bosnia and Herzegovina has held together with far less violence than many had feared. The country is not the multi-ethnic society it once was, but it is at peace. This is a formidable achievement of the peace accords. It is largely due to the longterm international presence and oversight - however flawed in many regards and international willingness to invest in the country's future.

21 G. Ambroso, "The Balkans at a crossroads: progress and challenges in finding durable solutions for refugees and displaced persons from the wars in the former Yugoslavia", UNHCR, New Issues in Refugee Research, Research Paper No. 133, Nov. 2006, 3-4. 


\subsection{Liberia}

The 14-year civil war in Liberia, which began with the overthrow of the military dictator, Samuel Doe, in 1989 and brought the warlord Charles Taylor to power, devastated the country. Liberia had long been ruled by an elitist and discriminatory leadership, but not previously subject to major political instability. After President Samuel Doe was killed in a coup d'état in 1990, Liberia experienced unrest and growing violence. An ineffective transition government was brought to a close when Charles Taylor was elected President in 1997. Thenceforth Liberia's criminal leaders sacrificed lives, property, and the rule of law in their quest for illegal wealth and power. When the Comprehensive Peace Agreement (CPA) was finally signed in Accra, Ghana, in August 2003 and Taylor sent into exile, more than 1 million Liberians had been displaced (refugees and IDPs combined) out of a population of 3.4 million.

The Peace Agreement $^{22}$ committed the newly established National Transitional Government of Liberia (NTGL) to abide by international and regional human rights instruments and to establish an Independent National Commission on Human Rights and a Truth and Reconciliation Commission to foster reconciliation. The Transitional Government was to "ensure the presence of security guarantees for the safe return and resettlement of refugees and internally displaced persons...”. ${ }^{23}$ At several points in the document, there is a call on the international community to fund security, political, and humanitarian programmes.

For two and a half years, Liberia was ruled by the NTGL which, while able to maintain stability with support from the United Nations Mission in Liberia (UNMIL), moved slowly and was characterized by corruption. The January 2006 election of President Ellen Sirleaf-Johnson opened a new and more vigorous phase in the peacebuilding process.

The first priority for the government, the UN, and international donors has been security, especially the integration of the very large number of ex-combatants. Former child soldiers were high priorities for DDRR programmes, as were women and children associated with the soldiers. This sense of urgency notwithstanding, a June 2004 UN Mission Report, released a year after the CPA was signed, complained that:

In Liberia as elsewhere in the region, a common concern was that considerable resources were devoted to disarmament and demobilization but that reintegration and rehabilitation, funded through voluntary contributions, were inadequately planned and resourced. ${ }^{24}$

\footnotetext{
22 The agreement was between the Government of Liberia, Liberians United for Reconciliation and Democracy, and Movement for Democracy in Liberia.

23 Art. XIV(4).

24 "Report of the Security Council Mission to West Africa, 20-29 June 2004", UN Security Council, S/2004/ 525, 2 Jul. 2004, para. 26.
} 
Thus, immediately following the disarmament and demobilization process, ex-combatants were returning to their places of origin and finding their reintegration packages (cash, training, and credits) to be lacking. This being the case, their presence presented an unwelcome burden on the community, which compounded bitter resentment over the suffering that the armed parties had caused during the conflict. The same UN Report continued by noting the pleas from civil society representatives that "genuine reintegration had to involve whole communities, including non-combatants." 25 Within a period of 2 years, reintegration programmes improved and other vulnerable segments of the Liberian population were gradually incorporated into rehabilitation and reintegration programmes. Since 2006, reintegration assistance has been made available across the board and relations among and between returnees of all categories and the local population has improved. IDPs, returning refugees, and former combatants have all received return packages, although the former soldiers have generally been better served.

Part Nine of the CPA, entitled Post-Conflict Rehabilitation and Reconstruction, asks for international support for the return of refugees and for IDP settlement, referring specifically to non-combatants and vulnerable groups. The agreement foresees a strong role for the Liberia Refugee, Repatriation and Resettlement Commission (LRRRC), among many other autonomous commissions. The agreement does not contain the detailed list of issues on behalf of IDPs (for example, education, documentation, land dispute resolution mechanisms) that are found in the Guatemalan, Bosnian, and other agreements. Rather it addresses needs relevant to the war-affected population overall, in other words the majority of Liberian citizens. There is no doubt, however, that both the transition government and the present government have been committed to finding solutions to the displacement of both refugees and IDPs.

The LRRRC has worked closely with UNHCR and as of the end of 2008 was still assisting in the return of Liberian refugees from the West African subregion. $^{26}$ In addition, UNHCR has had responsibility for IDP return, supported by WFP, IOM, and UNMIL. The return process was seriously underway by mid-2005. In April 2006, UNHCR announced that the process was complete and that 314,000 IDPs had registered and received return assistance packages. That year, UNHCR closed the IDP camps. Nevertheless, large numbers of IDPs have stayed in the camps, often with the hope of becoming permanent settlers in the areas of the camps. Others are in new informal camps, and the largest numbers by far are in Monrovia, the capital, and other cities. They are unwilling to return to their villages of origin despite the fact that Liberians are traditionally

25 Ibid.

26 Some 160,000 refugees returned to Liberia before UNHCR ended its programme in mid-2007. See UNHCR, Global Appeal 2008-2009, 2008, available at: http://www.unhcr.org/home/PUBL/ 474ac8d40.pdf (last visited 3 Feb. 2009). See also LRRRC, "Voluntary Repatriation Update", 14 Sep. 2008, available at: http://lrrrc.org/doc/Voluntary\%20Repatriation $\% 20$ Update $\% 20$ September $\% 2010 \%$ 202008.pdf (last visited 5 Jan. 2009). 
closely tied politically and ethnically to specific regions. This is not only because of the prevailing dismal material and economic conditions in return areas, but also due to fears that the traumatic experiences they endured in the past will be repeated.

In a comprehensive December 2006 report on displaced persons in postconflict Liberia, the Jesuit Refugee Service pleaded for more and better organized support for IDPs. ${ }^{27}$ The report distinguished between those who had returned to their own villages and those who wanted to settle in the places to which they had been displaced. The needs were equally great for both categories. There were very few agricultural inputs, such as seeds, fertilizer, and insecticide, or tools for small enterprises. Moreover, the war had resulted in widespread psychological problems which, in turn, had given rise to high levels of domestic violence. A sharp increase in sexual and gender-based violence is one of the most pernicious legacies of the conflict. Liberian women, now frequently heads of families, were able to take advantage of educational opportunities in the IDP camps but can do little with their new skills in their home villages.

In December 2006, The Economist magazine argued that the Liberian state "hardly exists" outside the major cities, citing the absence of police and state institutions. The few civil servants to be found were neither qualified nor sufficiently paid and some 85 per cent of all Liberians remained jobless. ${ }^{28}$ A March 2006 UN Progress Report underscores the consequences of weak state presence:

Civil administration, which should provide a safety net for vulnerable populations, is also largely absent at the county and district levels, which seriously limits the prospects for an early transition from relief assistance to sustainable rehabilitation and recovery in many communities. ${ }^{29}$

In June 2006, the UN Mission reported that disputes over land and property were on the increase as returning refugees, IDPs, and former combatants returned to the same places. Such disputes, if they turned violent, could destabilize the countryside. ${ }^{30}$ In November 2007, the UN Common Humanitarian Action Plan highlighted the still vital need for sustainable reintegration of refugees and IDPs in areas of return. ${ }^{31}$

\subsection{Burundi, 1972-2008}

In the approximately 40 years since independence, Burundi has had few sustained periods of peace. The country experienced intense ethnically driven civil conflicts, the most deadly of which broke out in 1993. During the years of conflict, more than 17 per cent of the Burundi population was forcibly displaced

27 JRS, Six Months after the Official Closing of the Camps, op. cit. 1.

28 "Peace isn't enough", The Economist, 16 Dec. 2006, 48.

29 UN S/2006//159, 14 Mar. 2006, para. 35.

30 UN S/2006/376, 9 Jun. 2006, para. 14.

31 IDMC, "Liberia: Key Challenge is Ensuring Sustainability of IDP Return”, 3 Aug. 2006. 
as refugees - an estimated 753,000 to Tanzania - or as IDPs. ${ }^{32}$ The Tanzanian government finally closed the camps in 2008 .

A series of negotiating sessions in Arusha, Tanzania, during the 1990s brought about a comprehensive Peace and Reconciliation Agreement on 28 August 2000, between the Tutsi-dominated government and its mainly Hutu opponents. But another 2 years passed until the main rebel forces signed a ceasefire in December 2002. In August 2005 a Hutu President, Peter Nkurunziza, was elected and formed an ethnically representative government devoted to further improving ethnic relations. Although one of the armed opposition Hutu groups (the National Liberation Forces) did not sign the ceasefire agreement and continued to disrupt security and violate human rights into 2006, conditions in most of the country by that year allowed large-scale return movements. ${ }^{33}$ By the end of 2008, UNHCR estimated that more than 470,000 Burundians had returned home from Tanzania and other asylum countries over the past 6 years. ${ }^{34}$

Due to the prolonged nature of the peace process, the Arusha Peace and Reconciliation agreement was, in effect, 6 years out of date before it could be systematically implemented. The 2000 Burundi agreement, like the Guatemala agreement referred to above, held return and reintegration to be a central goal. Its general language affirmed rights for all Burundian citizens in this ethnically divided nation to freedom of movement, equal access to public services and, to the extent possible, a dignified life. The Agreement specifies that women and men share equally in these rights and that Burundi's ethnic communities are to be protected. The major victims of past insecurity and violence, the Agreement states, include "individuals forced to flee from their original places of residence into exile, settlements and camps" (article 7a).

Protocol IV of the Arusha Agreement, entitled Reconstruction and Development, states the first priority to be support for "rehabilitation and resettlement of the refugees and sinistrés (displaced)" and pledges to "seek the support of other countries and international and non-government organizations in carrying out this responsibility" (article 2.1). The Protocol created a National Commission for the Rehabilitation of Sinistrés (CNRS) to work with international entities. It was charged with overseeing and coordinating these responsibilities, drawing up a plan of priorities, conducting a census, arranging logistics for reception and reintegration, and making sure all returnees in need received food aid, health care, education and social services, and that

32 "Report of the Secretary-General to the Security Council on the Situation in Burundi", S/2003/1146, 4 Dec. 2003; UNHCR, Global Report, Burundi, 2005; S. F. Martin and T. Hiddleston, "Burundi, a case of humanitarian neglect", in N. Van Hear and C. McDowell (eds), Catching Fire: Containing Forced Migration in a Volatile World, Lanham, Md. USA, Lexington Books, 2006.

33 In 2006, repatriations were at about 38,000, significant though somewhat short of the 50,000 2006 target. UN, "Ninth Report of the Secretary-General on the United Nations Operation in Burundi", S/2006/994, para. 44.

34 UNHCR Press Briefing, “Tanzania: Nduta Burundian refugees relocated as camp closes”, 19 Dec. 2008, available at: http://www.unhcr.org/news/NEWS/494b7e302.html (last visited 3 Feb. 2009). 
receiving communities received assistance in reconstruction and rebuilding infrastructure. Finally, the CNRS was asked to mobilize a special fund for the displaced, drawing both from state funds and international cooperation.

Land has been the most divisive issue in Burundi's recent history. Article 8 of the Agreement promised to enforce measures of restitution, compensation, or indemnification when justified by land seizures. The Sub-Commission on Land must, in the performance of its functions, ensure the equity, transparency, and good sense of all its decisions. It must always remain aware of the fact that the objective is not only restoration of property to returnees, but also reconciliation between the groups as well as peace in the country [article $8(\mathrm{k})$ ].

In November 2005, after the government transition, the UN Mission in Burundi (ONUB) reported that refugee returns had tripled in the previous 4 months, and the IDP population had decreased from 145,000 in 2004 to 100,000 . However, the above cited UN Report of November 2005 already expressed concern.

Many internally displaced persons and refugees have returned to areas devastated by war, finding their homes destroyed and their land occupied, which often leads to disputes. The situation of women returnees, particularly widows, is further exacerbated by the lack of adequate legislation to address their inheritance and land access rights.

Significant numbers of Burundians have remained reluctant to return to the rural communities they fled. Economic conditions in the rural areas continue to be miserable, and subject to sporadic fighting. Moreover, criminal violence is replacing the former political violence in some parts of the country. ${ }^{35}$

In August 2006, the President inaugurated a twenty-three member National Commission of Land and other Property, as foreseen in the Peace Agreement, complemented by four sub-commissions, to handle issues ranging from property dispute mechanisms to environmental considerations. ${ }^{36}$ The Commission still operates at the national, provincial, and commune levels, and faces a daunting challenge. The government is revising existing laws on land management so that land reform recommendations can more easily be legislated. The government seeks to identify unoccupied productive land, but with little success. Consequently land disputes are increasing. ${ }^{37}$ That there are continuing reports of human rights violations against opposition figures intensifies fears. Government officials in 2008 confirmed that among the repatriates alone,

35 "Fifth Report of the Secretary-General on the United Nations Operation in Burundi", 21 Nov. 2005, S/2005/728; UNHCR, Global Report, op. cit. 32.

36 See Integrated Regional Information Networks (IRIN), "Burundi: fighting for land", 6 Oct. 2008, available at: http://unhcr.org/refworld/doc/docid/48eb0bf51e.html http://www.unhcr.org/cgi-bin/texis/vtx/refworld/ rwmain?page $=$ printdoc\&amp; docid=48eb0bf51e (last visited 3 Feb. 2009); United Nations Peacebuilding Commission, "Community Recovery and Peacebuilding in Burundi: A Background Paper Prepared by the UN Integrated Office in Burundi (BINUB)”, 3 May 2007.

37 Ibid., 6 Oct. 2008. 
some 15 per cent were landless ${ }^{38}$ and the figures for returning IDPs were probably more dramatic.

The government has made rural development a priority and the attention is welcome, but for the present the economic prospects in rural Burundi are poor. Younger IDPs, moreover, have little experience of, or attraction to, subsistence agriculture. Potential returnees who have lost their sources of livelihood and/or their interest in subsistence farming under poor conditions cannot generally find productive alternatives in the rural areas and their prospects in cities are only slightly better. In addition to the IDPs who remain in camps, unknown numbers sought refuge during the conflict in the capital, Bujumbura, or other cities, where they are likely to remain. The IDP influx has swollen the population of Bujumbura, where the infrastructure has badly deteriorated and there are few jobs for the poor.

It has not been possible for Burundi's government to realize most of the goals on this difficult menu at this early date. Nor is it realistic to expect otherwise. It is, however, urgent to take steps to ensure that the Burundians returning from refugee and IDP camps can resume productive lives. The UN agencies for their part, are still delivering relief to meet basic needs. Programmes underway since 2004, funded by the World Bank, to implement disarmament, demobilization, and reintegration (DDR) programmes for former combatants, also offer limited benefits to other war-affected segments of the population. Refugees (but not IDPs) receive packages to assist their return. Lacking specific programmes, IDPs needs "fall through the cracks". The UN Peacekeeping Mission has been replaced by the Integrated Office for Burundi (BINUB). Its mission is broader than oversight of the measures in the peace agreement and is linked to poverty alleviation, human rights, and peacebuilding.

Burundi is one of the first countries to be placed on the agenda of the UN Peacebuilding Commission, whose mandate encompasses good governance, strengthening rule of law, community recovery, and land ownership. Recovery and land issues are major concerns. The Commission's Strategic Framework affirms some 260,000 returnees in Burundi to be without land. They have typically found their properties already occupied by others or that they have been allocated for public infrastructure projects by the state. ${ }^{39}$ Unless lasting solutions are found to the land issue it is likely to constrain socio-economic reintegration and to exacerbate conflicts and insecurity in rural areas. ${ }^{40}$

\footnotetext{
38 Ibid.

39 "Identical letters dated 21 June 2007 from the Chairman of the Burundi Configuration of the Peacebuilding Commission to the President of the Security Council, the President of the General Assembly and the President of the Economic and Social Council”, PBC/1/BDI/4, 22 Jul. 2007, para. 34.

$40 \quad$ Ibid., paras. 35, 37.
} 


\section{Prolonged and unsuccessful peace processes}

What can be done when peace negotiations fail over many years and displacement is protracted? The dominant view among humanitarians is that IDP solutions cannot and should not be held hostage to negotiated agreements. The condition of IDPs during conflict can be and is being mitigated by application of the Guiding Principles on Internal Displacement. The Guiding Principles have been supported by human rights advocates, civil society groups of all kinds, and by most government officials in the places where the displaced have sought refuge.

Since IDPs have often been driven out by actions of the warring factions, their future place in post-conflict society is very much on the agendas of negotiating parties. On the positive side, the adversaries are almost always prepared to acknowledge that displaced persons and refugees are victims of the conflict and that society has a responsibility toward them. On the negative side, the parties to ongoing peace negotiations are more than likely to use IDP issues to their own political advantage, withholding resolution of their status to gain concessions from the other side. Most discouraging, hard won successes are regularly undone by renewed conflict.

Outside formal procedures, civil society advocacy, combined with positive local government responses and international support, have improved the situation for significant numbers of IDPs. The extent to which civil society peace advocacy has been led by women is particularly noteworthy. Efforts to ameliorate the situation of IDPs are unquestionably part of peace processes, although not cast in political terms. In Colombia, Georgia, and Sri Lanka, for example, the same groups that advocate on behalf of IDPs also participate in large and vibrant peace movements. To ameliorate the IDP situation while conflicts persist means, at a minimum, making it possible for them to access needed services and employment during their displacement, helping them to integrate and to lead productive lives in safety. In several countries studied for this article, IDP advocates and IDP organizations have supported more proactive measures to facilitate return, restore property, and enable local integration. International organizations and donors have played important roles in funding peace communities, sustaining IDP settlements, helping to reconstruct and restore property, and putting pressure on authorities to comply with the Guiding Principles on Internal Displacement.

National governments have enacted measures intended to redress wrongs that IDPs have suffered during ongoing conflicts. An interesting example is the Government of Turkey. It has not reached a negotiated settlement with the insurgent Kurdish Workers' Party (PKK) but it significantly modified its repressive policies toward the Kurdish population in Anatolia by materially supporting return movements to villages destroyed by the Turkish army. In 2004, the government promulgated a Law on Compensation for Damage Arising from Terror and Combating Terror, known as the Compensation Law, 
for forcibly displaced Kurds. ${ }^{41}$ In its wording (although apparently not in its implementation to date), the law provides for far-reaching compensation for farmers forcibly displaced by over a decade of conflict. Efforts to make amends for two decades of hostility toward the Kurdish population coincided with a decline in attacks on the PKK side but by 2007 violence and armed struggle had been renewed. Turkey's wish to enter the European Union and to be seen as in conformity with the rulings of the European Court of Human Rights, however, still serve as strong incentives for humanitarian policies. ${ }^{42}$

The Colombian and Sri Lankan governments have also initiated actions to encourage return, to provide the bases for property restitution and compensation, and to facilitate IDP integration. Neither country has finalized a peace accord, but agreements reached at both national and local levels have at times opened some spaces for coexistence and reconciliation.

In Colombia, where there are some 3-4 million IDPs (depending on counting methodology), the government has acceded to all relevant international and regional humanitarian accords and has established a nationwide network of assistance. A government project, funded by the World Bank and many other donors, put in place a mechanism to register and protect the assets of internally displaced populations. It operates on a small scale. Nevertheless, the Constitutional Court in 2004 ruled that the state system was not meeting its obligations and had thereby violated the rights of the displaced. ${ }^{43}$ In 2006 the government reached an agreement - not a peace accord - with the paramilitary units. The latter promised to demobilize and disarm, and to compensate victims. The categories of victims entitled to compensation, however, do not include the vast majority of the persons they had displaced and the agreement has not prevented paramilitary units from reforming and rearming. Moreover, the left-wing insurgents in the Revolutionary Armed Forces of Colombia (FARC), who were not a party to the negotiations, continue to fight.

The Sri Lankan government has created an extensive national, regional, and local bureaucracy (of mixed efficacy) to help IDPs return and/or settle locally or elsewhere in the country. While the 2002 cease fire was in place, thousands of IDPs were assisted to return over a period of about 2 years. As part of the peace talks of 2002-03, the Liberation Tigers of Tamil Eelam (LTTE) and the Sri Lankan government committed themselves to humanitarian solutions and formed a joint Sub-Commission on Rehabilitation Needs in the North and East. During the Sub-Commission's brief period of operation, the LTTE and the government collaborated in humanitarian efforts on behalf

41 Law on Compensation for Damage Arising from Terror and Combating Terror, Jul. 2004.

42 Turkish Economic and Social Studies Foundation (TESSF), "Problem of Internal Displacement in Turkey: Assessment and Policy Proposals”, Dec. 2006, 16-18, 24; TESSF, NRC, and IDMC, Overcoming a Legacy of Mistrust: Toward Reconciliation between the State and the Displaced, May 2006, 33-40.

43 The ruling, known as T-25, referred to the 1997 law that established the legal basis for the national assistance. 
of IDPs. Insurgents frequently took similar actions in territories under their control. The results were mixed. The cease fire ended in 2007 and the renewed conflict has created thousands of new IDPs. The displaced who returned during lulls in the conflict are currently being displaced again. International assistance at this point is minimal.

In sum, there is no doubt that countries still lacking peace agreements are able to improve IDP conditions. In most cases this has come about more as a response to internationally funded programmes and pressures from IDP advocates and international agencies. Important as these improvements are, they fall short of addressing - much less resolving - the underlying insecurity, injustice, and discrimination that IDP populations face.

\section{Conclusions and recommendations}

\subsection{Peace agreements alone do not ensure IDP safety}

Once a peace agreement has been reached the well-being of IDPs depends on the degree of compliance with the full range of provisions in the accord. Achieving IDP rights and well-being depends both on addressing specific IDP issues and fulfilling broader goals of security, human rights, and governance, at both local and national levels. Protection continues to be as important as humanitarian assistance but receives less attention. When displacement has come about due to actions of still powerful entities, the same entities may be hostile toward the returnees after return, even if the conflict has officially ended. IDP returnees invariably experience tensions as they strive to recover lost and stolen properties.

\subsection{Better information gathering mechanisms are needed}

Monitoring either IDP returnees or those resettled elsewhere during and after conflict is admittedly difficult because the locations in question may be dangerous and/or difficult to access. Prior to peace, information about the potential for return, and integration in conflict-prone areas comes largely from local and international human rights organizations and religious sources who are present but whose major focus is usually on denouncing abuses. UNHCR, IOM, and government agencies report on successful return events, but it is difficult to gauge the extent or duration of these successes. Continued international support and monitoring are essential.

\subsection{Present mandates for international monitoring of IDPs following peace are inadequate}

There is no agency specifically charged to monitor the post-conflict IDP situation or to evaluate governments' performance. Professor Walter Kälin, the Representative of the Secretary-General on the Human Rights of IDPs, 
undertakes missions to a large number of countries where IDP issues are prominent, ${ }^{44}$ but lacks resources to monitor these countries systematically. The UN Missions that provide the most comprehensive monitoring of compliance with peace agreements, as noted, devote relatively little effort to IDPs, even if the agreement in question has made IDP solutions a central issue. (Measures relating to disarmament and demobilization of former combatants are more carefully monitored because compliance is seen as critical to security.) UN peacekeeping missions, moreover, end their tasks at an early stage of post-conflict reconstruction when the situation for returnees may still be in flux. These missions are replaced within a few years by more development-oriented international agencies that tend not to view the IDPs or returnees as a special category.

\subsection{More sustainable international support for reintegration is essential}

The role of international actors during peace negotiations has been extremely important, and the parties to virtually all contemporary peace agreements expect continued international support in fulfilling the agreements. While donors and international agencies have played fundamental roles in early recovery, assistance is almost always withdrawn or reduced too soon to sustain the reintegration of IDPs or other war-affected populations. The longstanding inadequacies of coordination and planning among international agencies, NGOs and donors have been especially evident in the lack of follow-up and attention to recently returned or resettled IDPs and refugees. However, there continue to be serious efforts to improve performance in this regard.

\subsection{Government actions may conflict with international goals}

New governments in war-torn countries are typically slow in fulfilling commitments made in peace agreements. Donors often respond to disappointing results on the part of governments by supporting separate projects rather than trying to reinforce or reform the government programmes they believe to be badly managed (and which very often are). This serves to reinforce the present pattern of favouring humanitarian projects implemented by NGOs over investments in government development priorities.

\subsection{The roles of national oversight entities need more analysis}

There are too little data to draw conclusions about the performance of national oversight entities, but their importance should not be understated. They are the counterparts of international agencies and NGOs working with or on behalf of IDPs and the focal points for solving problems that arise in fulfilling national obligations towards IDPs.

44 As for instance to El Salvador and Cambodia in 1993, although at that time he was not yet Representative. 


\subsection{Compliance with peace agreements depends on local authorities}

Fulfilling commitments to IDP rights, provision of services, resolution of conflicts, recovery of property, and so forth depends to a large extent on the will and ability of local authorities to implement the agreements and on the relationships between former IDPs and these authorities. This remains the case both before and after the signing of peace agreements. After conflict, local governments are often still weak, but traditional leaders in many instances are able to manage integration challenges successfully. In a number of reported cases, local officials and traditional leaders have taken the lead in ensuring peaceful integration. In other instances, authorities in power favour the claims of people who have occupied IDP land and property since the latter fled.

\subsection{Weak local institutions need support}

Peace agreements promise to facilitate recovery of land and property abandoned, lost, or stolen in conflict. Governments enact legal mechanisms to this end, sometimes before conflict has ended. International programmes support returns to places of origin. Nevertheless, in countries emerging from conflict, the state presence, especially in rural areas, often remains weak for years and judicial mechanisms do not function as they should. It also takes many years to restore infrastructure, resources, and economic opportunities in rural areas and, in the meantime, returnees to these areas often leave again as economic migrants.

\subsection{Urban integration programmes are needed}

Large numbers of IDPs normally seek refuge in cities. At the end of conflict, IDPs who have taken refuge in larger towns and cities, as well as a high proportion of returning refugees, may often decide not to return to their rural areas of origin. They make their choices based on a range of factors, such as the inaccessibility of their original communities, landmines, the absence of economic opportunities, their children's education, their own growing disinterest in rural living, and so forth. Peace agreements affirm that IDPs and everyone else can live where they choose, but advocates, governments, and donors are reluctant to make support for the integration of urban IDPs a priority. Governments and donors continue to promote return movements to communities of origin as the preferred goal, even when rural areas cannot sustain returnees' livelihoods.

\subsection{IDPs and other war-affected populations share common problems}

Peace agreements address IDPs and refugees together in most instances, as do post-conflict oversight missions. In post-conflict situations, the distinctions tend to blur. Prima facie refugees, rejected asylum-seekers, and even voluntarily repatriated refugees often join the ranks of the former combatants and internally displaced in their countries of origin. For a variety of reasons they do not return to their places of origin. When, as is all too often the case, peace 
agreements break down and fighting is renewed, former refugees and former IDPs are as likely as not to be affected and to flee once again.

\subsection{DDR programmes impact all war-affected persons}

Returning and resettled IDPs, refugees, and former combatants are often found in the same locations. The opportunities available to these different groups of people vary. International peacekeepers, national authorities, and donors devote greatest attention to former combatants. The programmes associated with DDR are more than justified. They enable and encourage young men and sometimes women, as well as child soldiers, who lived by arms to become useful civilians. Nevertheless, the benefits for former combatants which are not available to the IDPs and refugees they may have forcibly displaced, produces tensions. The latter two groups see themselves as, and often are, at a serious disadvantage. On the positive side, the community-based approaches now being adopted by some donors, including the United States Agency for International Development (USAID) and UN agencies, help to reduce inequities. On the negative side, all too often the reintegration and rehabilitation components of DDR for ex-combatants are under-funded, and there are even fewer resources for IDPs.

\subsection{Compensation is difficult but the issue should not be bypassed}

Since it becomes unlikely after many years of absence that families will return en masse to their places of origin, programmes for compensation and indemnification are as important as property recovery. Although the right to compensation is sometimes noted in peace agreements, functioning compensation/ indemnification mechanisms are rare. They were mandated in Bosnia and Herzegovina, for example, but are still being contested more than a decade after the end of the conflict.

\subsection{Gender awareness often declines after peace}

Thanks to greater awareness of gender as a factor in peacemaking, women are more frequently involved in peace negotiations and the resulting agreements recognize the need to frame solutions in gender terms. The fact that women are given special mention in the agreements, however, does not always translate into action after the conflict ends. In all countries that have experienced conflict, observers continue to cite continuing problems for women. They note particular problems in terms of rising levels of domestic violence and lack of access to property rights and legal titles, despite these topics being specifically covered in a number of peace agreements.

\subsection{Women's needs and potential are not uniform}

Women have been strongly represented in both peace movements and IDP groups. Widows and female heads of household are vulnerable to physical 
abuse and legal exclusion. As returnees or when temporarily settled, however, they have shown an ability to help themselves by organizing and taking advantage of opportunities offered by international cooperation. Women's perspectives on the optimal solutions for themselves and families are not at all homogeneous. For instance, some adapt well and prefer to remain in urban settings. Others would far prefer to return to more rural areas. Post-conflict programmes for IDPs and others should encourage and allow women to use their diverse skills.

\subsection{IDP organizations play small roles in peace negotiations}

IDPs have relatively few opportunities to make their preferences known to policy makers, authorities, and negotiators. All peace processes propose, and peace agreements confirm, that IDPs may choose whether or not they wish to return to their places of origin. International IDP advocates and donors have been important champions of IDP rights. Civil society groups consistently speak out on behalf of IDPs, but this does not equate with real representation. While some IDPs urge more robust programmes of integration within the peace process, others express fear that negotiating parties will compromise their right to return. This concern is not unreasonable. Compensation for lost and stolen property is high on the list of concerns of all IDP organizations, but low among donor and government priorities, albeit for understandable reasons.

\subsection{IDPs rarely maintain their organizations following peace}

Research from Central America shows that refugee and IDP groups that were once tightly organized weaken dramatically upon return and after peace. Once they leave their former camps and settlements, they are scattered and cannot maintain political action when they return or resettle. Therefore, they cannot effectively pressure for compliance with promises made to them. In Sudan, for example, IDP organizations reportedly strong in and around Khartoum were not re-established among returnees to Southern Sudan.

\subsection{The absence of firm peace limits but does not preclude improvements}

Much can be done to alleviate IDP misery and open options for them to lead productive lives. Nevertheless, for obvious reasons, incomplete peace agreements severely limit both durable return and integration even where conditions appear to be stable. As long as there is violent conflict waged at the expense of civilians, there is the risk of further displacement. Where control passes from one party to another, some groups of IDPs may occupy the homes of other IDPs who have previously fled, thereby magnifying the complexity of finding solutions to displacement. In conflict, IDPs are prime targets for recruitment by armed factions. Ongoing or sporadic conflict precludes the essential tasks of rebuilding judicial systems, disarming security forces, and investing in infrastructure and economic productivity. 